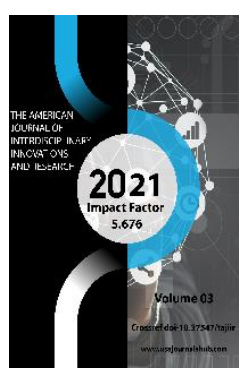

\title{
Namangan, The City Of Flowers
}

\author{
Bakhtiyor Nuriddinov \\ Lecturers Of The Department Of Fine And Applied Arts, Namangan State University, \\ Uzbekistan \\ Bakhtiyor Ruzinov \\ Lecturers Of The Department Of Fine And Applied Arts, Namangan State University, \\ Uzbekistan
}

\footnotetext{
Copyright: Original content from this work may be used under the terms of the creative commons attributes 4.0 licence.
}

\section{ABSTRACT}

This article analyzes the history, culture and art of Namangan, the ancient city of the Fergana Valley, as well as the works of scholars and the ones who have contributed to the development of our national spirituality.

\section{KEYWORDS}

History, art; the Timurid period; culture; period of awakening; Turkish language; literature; tourism, east; open-air museum, Sardoba (ice-house), Deep Street, Degrezlik, Poetry to Labbaytoga.

\section{INTRODUCTION}

On the naming of the city "Beautiful Namangan" and the history of its origin, the scholars such as H.Vamberi, VVBartold, Ya.G.Gulamov, Z.M.Akramov, A.Aliev, H.Hasanov, A.Juvonmardiev, Y.Kasimov, A.Muhammadjanov, I.Abdullaev, M.Diyori expressed different opinions in their books, pamphlets and articles. However, today it is difficult to give a definite answer to the question of when Namangan city appeared. So is the opinion of archaeologists. There is no written information or clear scientific opinion on the etymology of the term Namangan. 


\section{MATERIALS AND METHODS}

According to Is'hak Khan Ibrat's "History of Fergana", by the decree of Abdullokhan (1557 1598), the ruler of Bukhara, a city consisting of Sardoba (ice-house), Chukur Street, Degrezlik, Labbaytaga was built. The river side of the city was covered with white salt. That is why the city is called Namakkon (salt mine). However, the term "Namakkon" does not appear in any existing source in the Arabic script. The conclusion that Namangan was founded during the reign of Abdullah Khan also has no scientific basis. Mahmud Diyori's article "Again about the name of Namangan", which was published in the newspaper "Namangan Haqiqati" (July 6, 1974), described Namangan as Samangon, as in Firdavsi's "Shohnoma". Samangan is a city in present-day's Mazar-eSharif Province in northern Afghanistan. Mahmud Diyori interpreted the root of the term Namangan not as "Namak" but as "Namang" and described it as a pearl-shaped bead or oliboli (cherry) with a hole in the middle. An article by academician Abdulahad Muhammadjanov entitled "On the etymology of Namangan toponymy" published in the journal "Uzbek language and literature" (2003, No. 5, pp. 35-38) tried to solve the problem. According to the author, the term "Namangan" consists of three parts: the main syllable - "nav" (new), the middle syllable, that is the term "man", the last syllable - the adjective "gon". The article names the places where the word "nav" is used: Navobod, Navkat, Navkent, Nadih ... "On this basis, if the main part of the toponym" Namangan "is interpreted in the pronunciation of" nav ", there is no doubt that the city is actually called" Namangan ". Ismatullah Abdullah, Doctor of Philology, Professor, Honored Scientist of Uzbekistan, commented on the term "Namangan" as below ("Namangan Haqiqati", January 14, 2004): "the word "mon" is derived from ancient Pahlavi language and means palace, address, house".

\section{RESULTS AND DISCUSSIONS}

A. Muhammadjanov writes about the suffix "gon": "In fact, it was derived from the Sogdian word "kan "or" kanda. These words mean "to dig" and "to carve." Based on the above considerations, the city of Namangan, historically interpreted as "Namakkon", actually means "a new palace by the river", "a new tower by the river". The views of the writer Abdugani Abduvaliev, in this regard, are also noteworthy. He noted: "There were about 120 tribes and clans in Central Asia. Most towns and villages are named after tribes (this situation is expressed in history as an ethnotoponym. - B. R., B. I.). There are many places called "Naiman" and "Naimancha" in our region. Probably, in ancient times it was called "Naymangon", the place where the Naymans lived, and later the " $y$ " fell due to a slippage in pronunciation - "Tashkon", "Anjon". Orientalist-historian A. Juvonmardiev commented on the name of the city, calling it "Nomiygan" - "the city of saints and celebrities." H. Vamberi wrote, "It could be Namang-Marjon, Namangan-Marjon mine." Some historians interpret the term Namangan etymologically as Navmakon, meaning "New Place." Russian local historian V. In A Brief History of the Kokand Khanate (Kazan, 1886), Nalivkin regretted the difficulty of writing the history of the cities in the Fergana Valley, noting that there were no written sources and that unbelievable myths and legends were widespread. Thus, there is no universally 
accepted opinion about the toponym "Namangan". Moreover, the information in the available documents, although considered valuable sources for the science of history, none of which can be conclusive scientific evidence to determine the age of Namangan city. To do this, archaeologists, historians, orientalists, ethnologists and linguists must carry out complex research. Only then will it be possible to determine the date of formation of the city.

During the years of independence, great conditions have been created for determining the age of Namangan. In connection with the construction of the road-bridge, which began in February 2006 in the Chorsu district of the city, 10-11 meter pits were dug. The findings showed the presence of an archeological cultural layer in the area. In the analysis of cultural strata and finds, archaeologistscientist, academician On the advice of A.Askarov, a badraf (toilet) of the 10th-11th centuries was found in the Kotlovan section. Embroidered pottery of the X-XI centuries and copper coins of the Karakhanid period were found in its lower part. There is also an Arabic inscription on the pottery that wishes blessings and abundance to those who eat from this vessel. It is clear that the pottery was made for the market. The market is one of the important symbols of ancient cities. The State Inspectorate for Protection and Use of Cultural Heritage of Namangan region has come to some conclusions as a result of regular inspections at the construction site. The depth of cultural layers accumulated over the centuries reaches 10 - 11 meters. The main findings today are the remains of pottery from the Samanid and Karakhanid periods. Among them are colored glass fragments of the
Byzantine Empire and fragments of ceramic pottery with foam inscriptions, confirming that the Great Silk Road passed through Namangan. At the same time, fragments of glassware made in ancient Akhsikent, samples of ceramic pipes of different sizes were found at the site. Archaeological discoveries indicate that Namangan city is at least $1000-1100$ years old. In addition, artifacts dating to the Middle Ages were found during excavations by M.E.Masson in one of the oldest cemeteries in Namangan, Otbozori - "father of Central Asian archeology" in 1939-1940, located on the right bank of North Fergana Canal in the southern part of the Mangulik Cemetery. Summarizing the above considerations and evidence, it becomes clear that archeological excavations in the city area and the search for ancient manuscript sources are necessary, with the involvement of experts to study the original age and history of Namangan.

\section{CONCLUSION}

We believe that the new data will be an important help for researchers studying the architectural history of Namangan, especially the Fergana Valley, architects, historians, art critics and other professionals in determining its place in our historical and cultural heritage. In addition, we hope that the city of Namangan will be of interest to all who have heard about the history of this country, and will ensure that the region will attract more and more tourists from different parts of the country and the world.

\section{REFERENCES}

1. The order No.4680 of the President of the Republic of Uzbekistan on April 16, 2020 "On measures of radically 
improving the system of training in the field of Oriental Studies and increase scientific capacity."

2. Ismoilov $\mathrm{Yu}$. The Pride of Namangan Namangan: Namangan Publishing House, 1994.

3. Is'khak Khan Tura Ibrat. History of Fergana.-Tashkent: Ma'naviyat, 2005.

4. 19. Mirza Muhammad Haydar Ayazi. History of Rashidi.- Tashkent: Uzbekistan, 2011.

5. Kozakov T. Ahsi is the mother of Fergana cities.- Tashkent: Navruz, 2018.

6. Kozakov T., Ruzinov B., Vohidov A. Akhsikent in the eyes of Ibrat.Tashkent: Navruz, 2018.

7. Ruzinov B, Rejabova S, Ismoilov Yu, Qosimov A. Cultural heritage of Namangan region.- Namangan: Namangan, 2013.

8. Muhammad Obid Namangani. (Safarboev M. Rakhimov S.) - Tuhfat ulobidin and anis ul-ashiqin. Tashkent: Navruz, 2019.

9. Kozakov T, Ruzinov B, Vohidov A. Scholars of Fergana or Akhsikent, the cradle of the great. - Tashkent: Navruz, 2020.

10. Тошбеков Нурбек Ахмадович, Хамдамова Диловар Нуруллаевна, Хайитов Ёзил Косимович, Гидрологические основы использования дренажных сетей (по премире бухарской области). MONOGRAFIA POKONFERENCYJNA SCIENCE, RESEARCH, DEVELOPMENT \#26 v. 2 Познань/Poznan 27.02.202028.02.2020 186-189.

11. Toshbekov Nurbek Ahmadovich, Hayitov Yozil Kasimovich, Jumaeva Tozagul Azamovna. EFFICIENT USE OF
WATER RESOURCES OF THE AMUBUKHARA CANAL. ACADEMIK. An International multidisciplinary Research Journal 30.05.2020.15-18

12. Toshbekov Nurbek Ahmadovich, HayitovYozil Kosimovich, JumaeyaTozagul Azamovna, Nazarova Firuza Ahmedjanovna. The Formation of Water Collector-Resources Drainage Network of Zarafshan Oasisand the Questions of Recycling. TEST Engineering \& Management. May-June 2020 ISSN: 0193-4120 Page No. 27380 2738. 